\title{
THE ASSESSMENT OF TOXIC EMISSION FROM THE ENGINES OF THE W-3 HELICOPTER IN THE PREFLIGHT ENGINE RUN
}

\section{OCENA EMISJI ZWIĄZKÓW SZKODLIWYCH SPALIN Z SILNIKÓW ŚMIGLOWCA PZL W-3 SOKÓŁ W WARUNKACH PRÓBY PRZEDLOTOWEJ SILNIKÓW}

\author{
${ }^{1)}$ Krzysztof Cur, ${ }^{2)}$ Robert Kozłowski, ${ }^{3)}$ Jarosław Markowski, \\ ${ }^{3)}$ Jerzy Merkisz, ${ }^{3)}$ Jacek Pielecha \\ ${ }^{1)}$ Dowództwo Sił Powietrznych, ${ }^{2)}$ Inspektorat MON ds. Bezpieczeństwa Lotów, \\ ${ }^{3)}$ Politechnika Poznańska, Wydział Maszyn Roboczych i Transportu, \\ e-mail:pilot23@wp.pl; robert.w.kozlowski@o2.pl; \\ jarostaw.markowski@put.poznan.pl,jerzy.merkisz@put.poznan.pl; \\ jacek.pielecha@put.poznan.pl
}

\begin{abstract}
Helicopters are used in a variety of tasks like sea, mountain and land search and rescue, civil transportation or military operations. Their amount is growing, their ceiling is usually low, however, the exhaust emission from their engines is not restricted by any directive. That is why an attempt was made to determine the real exhaust emission. The research was done on the W-3 helicopter during the preflight engine run. Based on the results set the standard was created which reflects the working conditions of the engines during the test cycle. The research allowed to establish the unit emission of toxic gasses and then the influence on environment of the engines.
\end{abstract}

Keywords: exhaust emission

Streszczenie: Emisja zanieczyszczeń z napędów śmigłowców, objęta normami, dotyczy silników o mocy większej od $2 \mathrm{MW}$, przez co napędy nawet ciężkich śmigłowców transportowych nie sq objęte normami emisji spalin. Dlatego podjęto próbę oceny emisji zanieczyszczeń zawartych $w$ spalinach lotniczych silników śmigłowcowych. Badania przeprowadzono na śmigłowcu PZL W-3 Sokót podczas próby przedlotowej. Na podstawie uzyskanych wyników wstęnych pomiarów opracowano test badawczy odzwierciedlajacy warunki eksploatacyjne pracy tych silników.

Stowa kluczowe: emisja zanieczyszczeń 
The assessment of toxic emission from the engines of the W-3 helicopter...

Ocena emisji związów szkodliwych spalin z silników śmigłowca PZL W-3 Sokót...

\section{Wprowadzenie}

Większość zadań transportowych lotnictwa wojskowego wiąże się z procedurami szkolenia wojsk oraz działalnością Polskich Sił Zbrojnych poza granicami kraju. Powoduje to zapotrzebowanie na środki transportu lotniczego charakteryzujące się możliwościami przemieszczania dużej masy ładunku na możliwie dalekie odległości oraz możliwościami realizacji zadań transportowych wynikających z potrzeb działań w bliskiej odległości, rejonie walk, w zadaniach ewakuacyjnych, w przypadku klęsk żywiołowych. Do zadań pierwszego rodzaju wykorzystuje się samoloty, natomiast w przypadku działań drugiego rodzaju, pożądanym statkiem powietrznym do wykorzystania są śmigłowce [4].

Zapotrzebowanie na zadania transportowe dedykowane śmigłowcom przekładają się niemal bezpośrednio na wzrost liczby eksploatowanych tego typu statków powietrznych. Wzrost zapotrzebowania na środki transportu lotniczego wiąże się ze wzrostem negatywnego oddziaływania na środowisko naturalne w aspekcie hałasu oraz emisji związków szkodliwych zawartych w spalinach zespołów napędowych. W dalszym ciągu poważnym zagrożeniem jest emisja dwutlenku węgla oraz cząstek stałych - stanowiąca barierę rozwoju współczesnych silników spalinowych. Obecne przepisy dotyczące wpływu środków transportu lotniczego na środowisko wprowadzone przez EPA (Environmental Protection Agency Agencja Ochrony Środowiska), ICAO (International Civil Aviation Organization Organizacja Międzynarodowego Lotnictwa Cywilnego) zawarte w JAR 34 (Joint Aviation Requirements - przepisy określające normy emisji spalin), FAR 34 (Fuel Venting and Exhaust Emission Requirements for Turbine Engine Powered Airplanes - przepisy określające normy emisji spalin), dotyczą głównie emisji hałasu i związków szkodliwych spalin ze szczególnym uwzględnieniem tlenków azotu [3]. Dotyczą one silników turbinowych turbowentylatorowych i odrzutowych. Zawarto $\mathrm{w}$ nich wymagania aparaturowe i procedury realizacji testów o charakterze stacjonarnym, w zależności od warunków pracy silnika [7]. Silniki turbinowe o zastosowaniach śmigłowcowych sklasyfikowano w ujęciu całościowym norm, ale nie określono dla nich limitów emisji związków szkodliwych zawartych w spalinach.

Realizacja badań emisji związków szkodliwych spalin silników lotniczych $\mathrm{w}$ testach stacjonarnych może być wykorzystana do budowy algorytmów pozwalających ocenić rzeczywistą emisyjność statków powietrznych, a tym samym może przyczynić się do dalszego rozwoju ich napędów i zmniejszenia negatywnego oddziaływania na środowisko naturalne człowieka [1].

\section{Metodyka badań}

\section{Obiekt badań}

Badania emisji związków szkodliwych zawartych w spalinach turbinowego silnika śmigłowcowego wykonano z wykorzystaniem śmigłowca PZL W-3 Sokół (rys. 1), którego zespół napędowy stanowią dwa silniki turbo-wałowe PZL-10W (rys. 2). 
Podstawowe parametry silnika przedstawiono $\mathrm{w}$ tabeli 1. Badania emisji składników szkodliwych spalin przeprowadzono w warunkach rzeczywistej eksploatacji śmigłowca, podczas realizacji próby przedlotowej. Śmigłowiec PZL W-3 Sokół jest wyposażony w pokładowy rejestrator parametrów lotu, którego zadaniem jest rejestracja nie tylko takich parametrów jak prędkość i wysokość lotu, kąty położenia śmigłowca, ale również między innymi parametrów eksploatacyjnych silników. Przykładowy obraz z rejestratora lotu przedstawiono na rysunku 3.

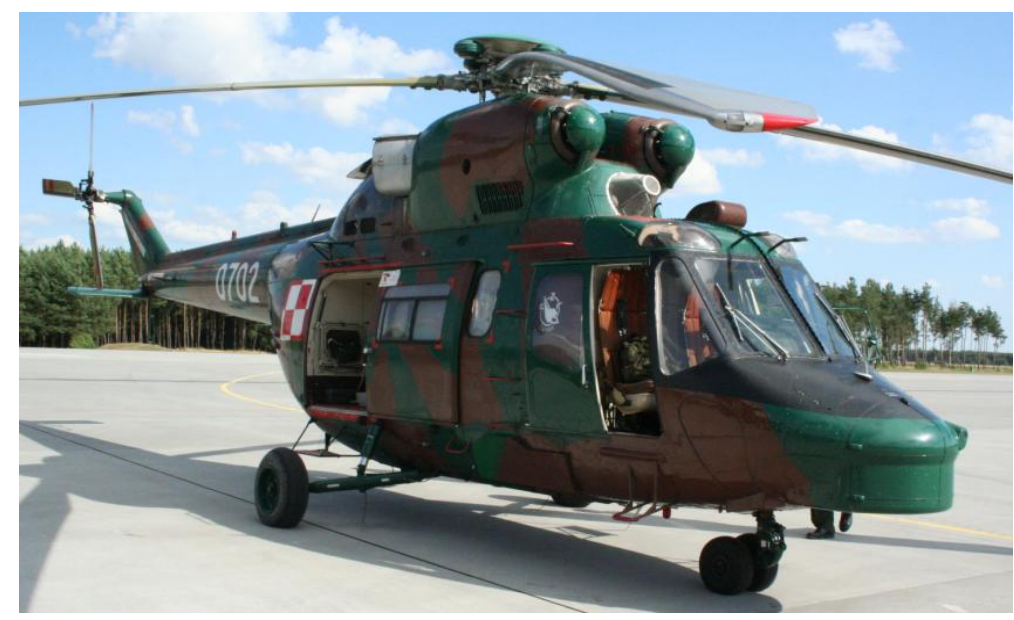

Rys. 1. Śmigłowiec PZL W-3 Sokót

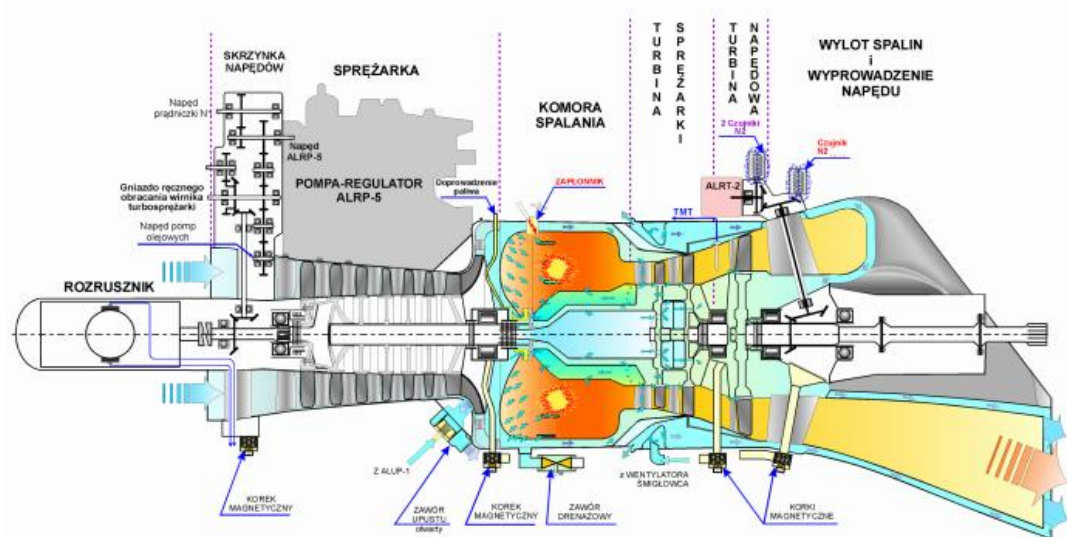

Rys. 2. Schemat ideowy silnika PZL-10W [5] 
The assessment of toxic emission from the engines of the $W-3$ helicopter...

Ocena emisji związów szkodliwych spalin z silników śmigłowca PZL W-3 Sokót...

Tabela 1 Podstawowe parametry silnika [2]

\begin{tabular}{|l|c|}
\hline Silnik & PZL-10W \\
\hline Moc [kW] & 660 \\
\hline Spręż [-] & 7,0 \\
\hline Zużycie powietrza [kg/s] & 4,5 \\
\hline Jednostkowe zużycie paliwa [kg/kWh] & 0,408 \\
\hline Wysokość [mm] & 400 \\
\hline Szerokość [mm] & 400 \\
\hline Masa [kg] & 150 \\
\hline
\end{tabular}

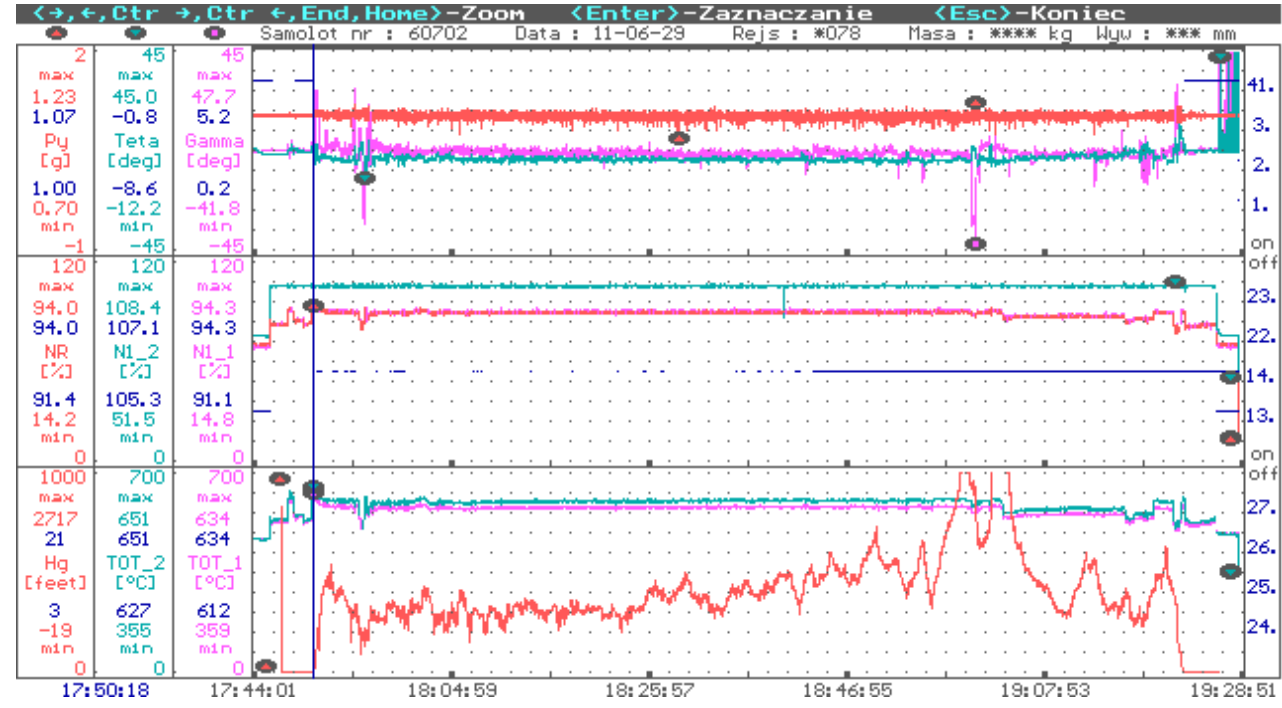

Rys. 3. Przykladowy obraz z rejestratora lotu

\section{Aparatura pomiarowa}

Pomiarów emisji składników spalin dokonano w rzeczywistych warunkach eksploatacji śmigłowca. Podejście takie wymagało zamontowania układu poboru spalin na śmigłowcu w pobliżu dyszy wylotowej, w sposób umożliwiający jego eksploatację. W tym celu wykorzystano proste elementy konstrukcyjne (rys. 4). Przewód doprowadzający próbkę spalin do analizatora przeprowadzono przez otwarte okno w przestrzeni ładunkowej śmigłowca. 

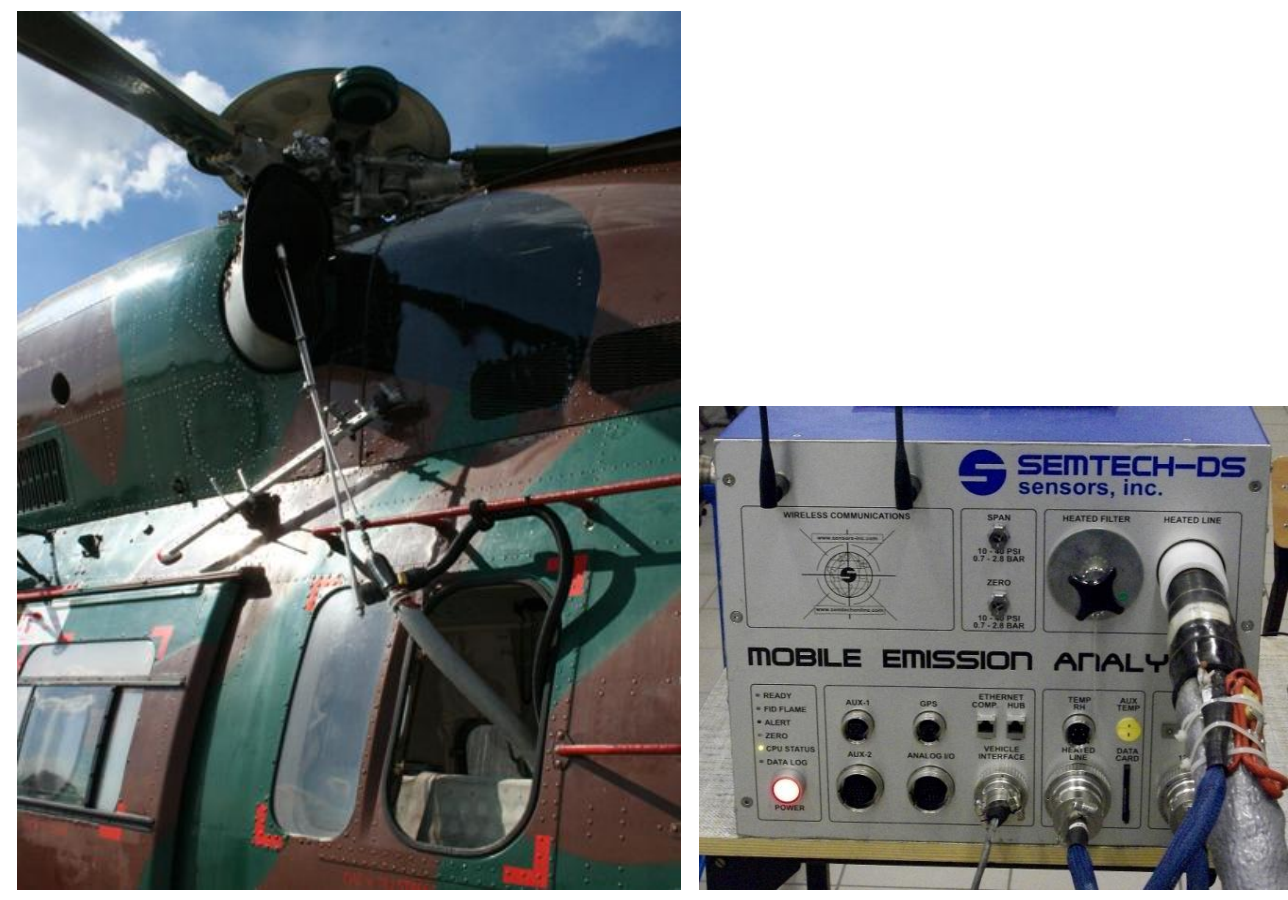

Rys. 4. Zamocowanie uktadu poboru spalin Rys. 5. Widok analizatora Semtech-DS na śmigłowcu $W$-3 Sokót

Do pomiarów stężenia związków szkodliwych spalin wykorzystano mobilny analizator Semtech-DS firmy Sensors (rys. 5). Analizator umożliwia pomiar stężenia tlenku węgla, węglowodorów, tlenków azotu oraz dwutlenku węgla (tab. 2). Semtech-DS jest analizatorem przeznaczonym głównie do monitorowania emisji z pojazdów z silnikami o zapłonie samoczynnym jak i iskrowym. Wszystkie podzespoły analizatora Semtech-DS zaprojektowano tak, aby jak najbardziej odpowiadały klasie laboratoryjnej urządzeń pomiarowych, a jednocześnie mogły sprostać specjalnym wymaganiom stawianym urządzeniom monitorującym emisję w środkach transportu. Spełnienie tych założeń wymagało maksymalnego obniżenia masy, wielkości i zużycia energii przez urządzenie, dużej odporności na drgania i wibracje, zmiany temperatury i inne czynniki zewnętrze mające wpływ na wyniki, przy jednoczesnym zapewnieniu dużej dokładności pomiarowej. Takie właściwości aparatury są wyjątkowo korzystne do realizacji pomiarów stężenia związków szkodliwych spalin generowanych przez zespoły napędowe statków powietrznych. 
The assessment of toxic emission from the engines of the W-3 helicopter...

Ocena emisji związów szkodliwych spalin z silników śmigłowca PZL W-3 Sokót...

Tabela 2 Charakterystyka mobilnego analizatora Semtech DS [6]

\begin{tabular}{|c|l|c|}
\hline Parametr & Metoda pomiaru & Dokładność \\
\hline $\mathrm{CO}$ & NDIR, zakres pomiaru 0-10\% & $\pm 3 \%$ zakresu pomiaru \\
\hline $\mathrm{HC}$ & FID, zakres pomiaru 0-10 000 ppm & $\pm 2,5 \%$ zakresu pomiaru \\
\hline $\mathrm{NO}_{\mathrm{x}}$ & NDUV, zakres pomiaru 0-3000 ppm & $\pm 3 \%$ zakresu pomiaru \\
\hline $\mathrm{CO}_{2}$ & NDIR, zakres pomiaru 0-20\% & $\pm 3 \%$ zakresu pomiaru \\
\hline $\mathrm{O}_{2}$ & elektrochemiczna, zakres pomiaru 0-20\% & $\pm 1 \%$ zakresu pomiaru \\
\hline
\end{tabular}

\section{Wyniki badań i analiza}

Podczas realizacji przedlotowej próby śmigłowca dokonano pomiarów stężeń związków szkodliwych zawartych w spalinach. Wyniki przeprowadzonych pomiarów stężeń $\mathrm{CO}, \mathrm{HC}, \mathrm{NO}_{\mathrm{x}}, \mathrm{CO}_{2}$ przedstawiono jako wartości pomiarowe dla kilku minut pomiaru począwszy od chwili przed uruchomieniem do kilku sekund po wyłączeniu silników (rys. 6). Przebieg próby dodatkowo rejestrowano za pomocą rejestratora parametrów lotu. Z uzyskanego zapisu wyszczególniono przebiegi parametrów eksploatacyjnych silników, które wykorzystano w dalszej analizie do określenia wartości chwilowych obciążenia silników (rys. 7).

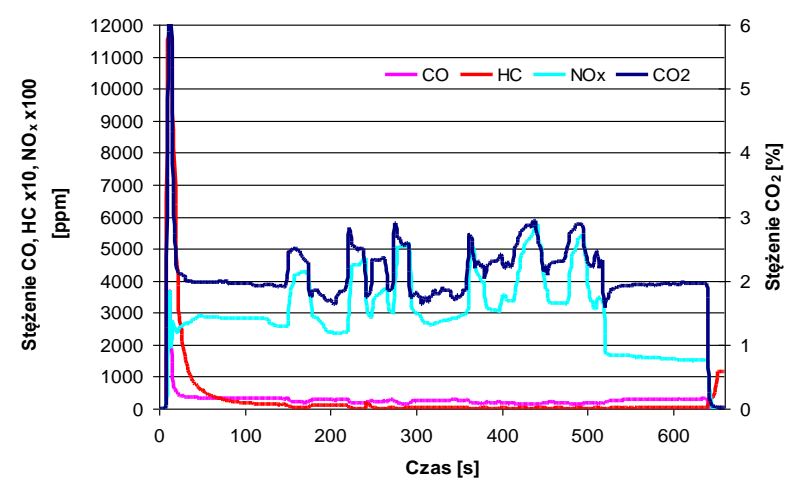

Rys. 6. Przebieg wartości stężenia poszczególnych zwiazków szkodliwych spalin podczas próby przedlotowej śmigłowca

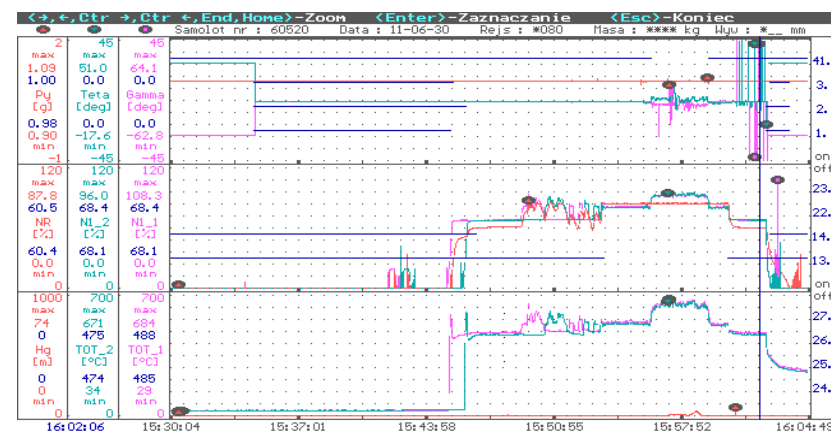

Rys. 7. Przebieg parametrów eksploatacyjnych silników zarejestrowany przez rejestrator parametrów lotu podczas próby przedlotowej 
W analizie obciążenia silnika pod uwagę były brane prędkość obrotowa turbiny wytwornicy spalin obydwóch silników N1_1 i N1_2, wyrażona jako procent wartości prędkości maksymalnej, oraz wartości temperatury za turbiną TOT_1 i TOT_2 przedstawione na wykresie w stopniach Celsjusza. Na przykładowym wykresie (rys. 7) jest przedstawiony przebieg sygnałów chwilowych stanów eksploatacyjnych śmigłowca podczas realizowanej próby. Początkowa część wykresu przedstawia uruchomienie przyrządów śmigłowca i czas weryfikacji systemów pokładowych. Następnie od połowy zarejestrowanego przebiegu obserwuje się uruchomienie silników: początkowo pierwszego, a następnie drugiego. Na podstawie zarejestrowanych przebiegów wyznaczono czasowe obciążenia silników (rys. 8). Podczas realizacji próby przedlotowej silniki pracują na obciążeniu około $20 \%$ obciążenia maksymalnego przez $24 \%$ czasu próby, na obciążeniach w zakresie $65 \div 75 \%$ obciążenia maksymalnego przez około $43 \%$ czasu, a na obciążeniu około $84 \%$ obciążenia maksymalnego pracują około $33 \%$ czasu trwania próby.

Na podstawie dostępnych charakterystyk przepływowych silnika PZL-10W oraz zmierzonej wartości chwilowego współczynnika nadmiaru powietrza określono natężenie spalin generowanych przez silnik $\mathrm{w}$ poszczególnych punktach obciążenia. Uzyskane wartości chwilowego natężenia spalin, pomnożone przez zmierzoną wartość chwilową stężenia związku szkodliwego, dały w wyniku chwilowe wartości natężenia emisji poszczególnych związków szkodliwych spalin podczas realizowanej próby (rys. $9-12$ ).

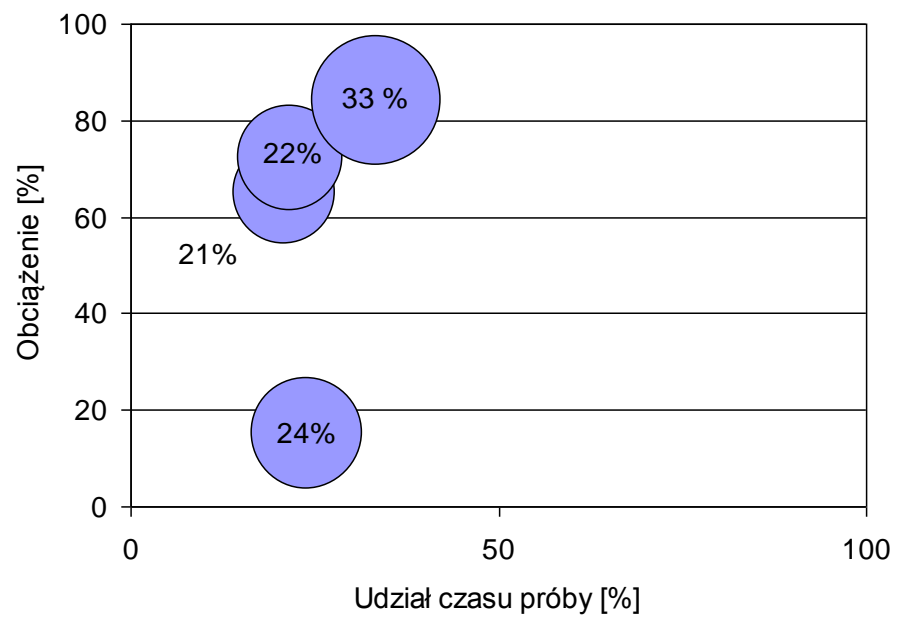

Rys. 8. Obciażenia czasowe zespolu napędowego śmigłowca W-3 Sokót podczas próby przedlotowej 
The assessment of toxic emission from the engines of the $W$-3 helicopter... Ocena emisji związów szkodliwych spalin z silników śmigłowca PZL W-3 Sokót...

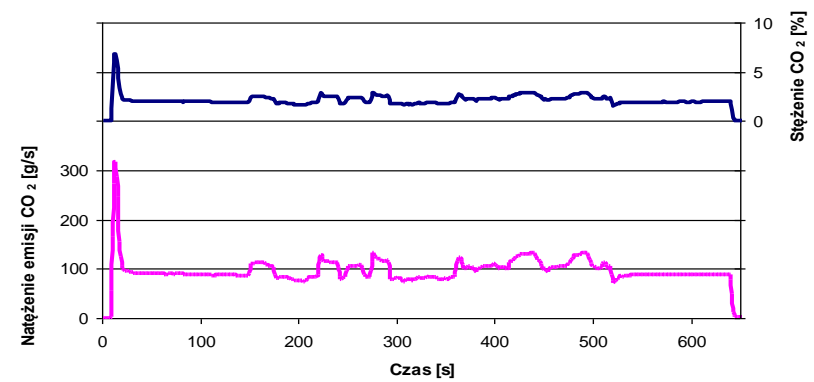

Rys. 9. Przebieg wartości chwilowej stężenia i natężenia emisji $\mathrm{CO}_{2}$ w spalinach podczas realizowanej próby

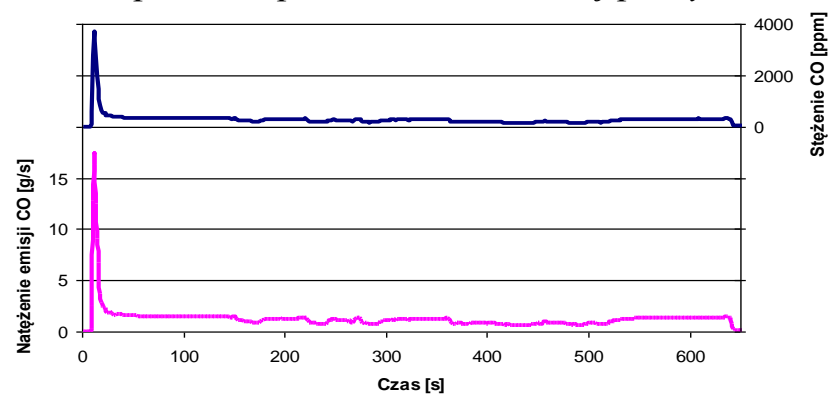

Rys. 10. Przebieg wartości chwilowej stężenia i natężenia emisji CO w spalinach podczas realizowanej próby

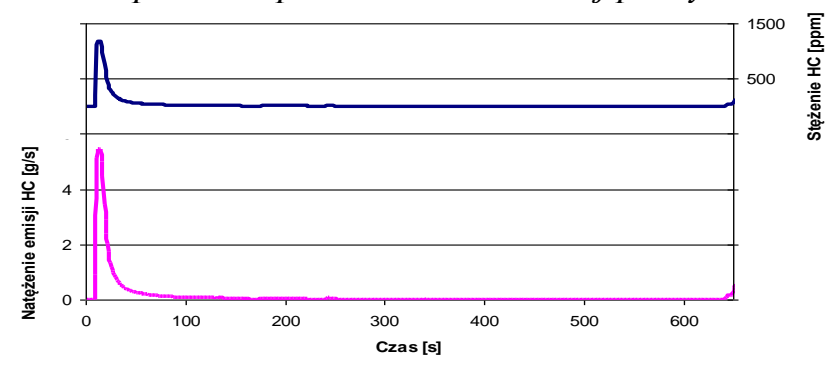

Rys. 11. Przebieg wartości chwilowej stężenia i natężenia emisji HC w spalinach podczas realizowanej próby

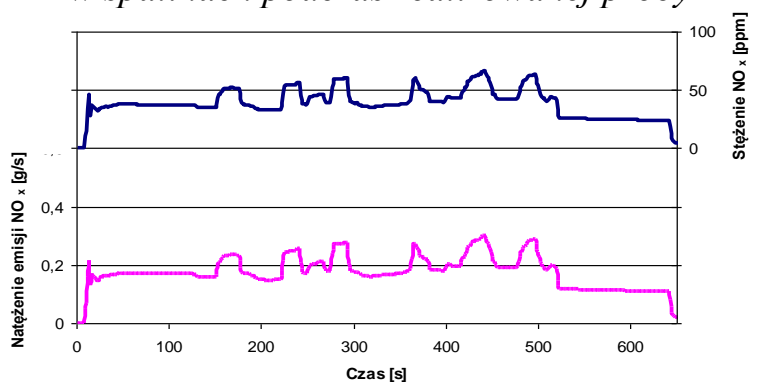

Rys. 12. Przebieg wartości chwilowej stężenia i natężenia emisji $N O_{x}$ w spalinach podczas realizowanej próby 
Poddając zestawieniu przebiegi wartości chwilowej natężenia emisji poszczególnych związków szkodliwych z udziałem czasu trwania chwilowych wartości obciążenia, uzyskano wartości masy związków szkodliwych spalin wyemitowanej podczas realizowanej próby (rys. 13). W trakcie próby wyemitowano około $74000 \mathrm{~g} \mathrm{CO}_{2}$, około $600 \mathrm{~g} \mathrm{CO}$, około $12 \mathrm{~g} \mathrm{HC}$ i około $160 \mathrm{~g} \mathrm{NO}_{\mathrm{x}}$.

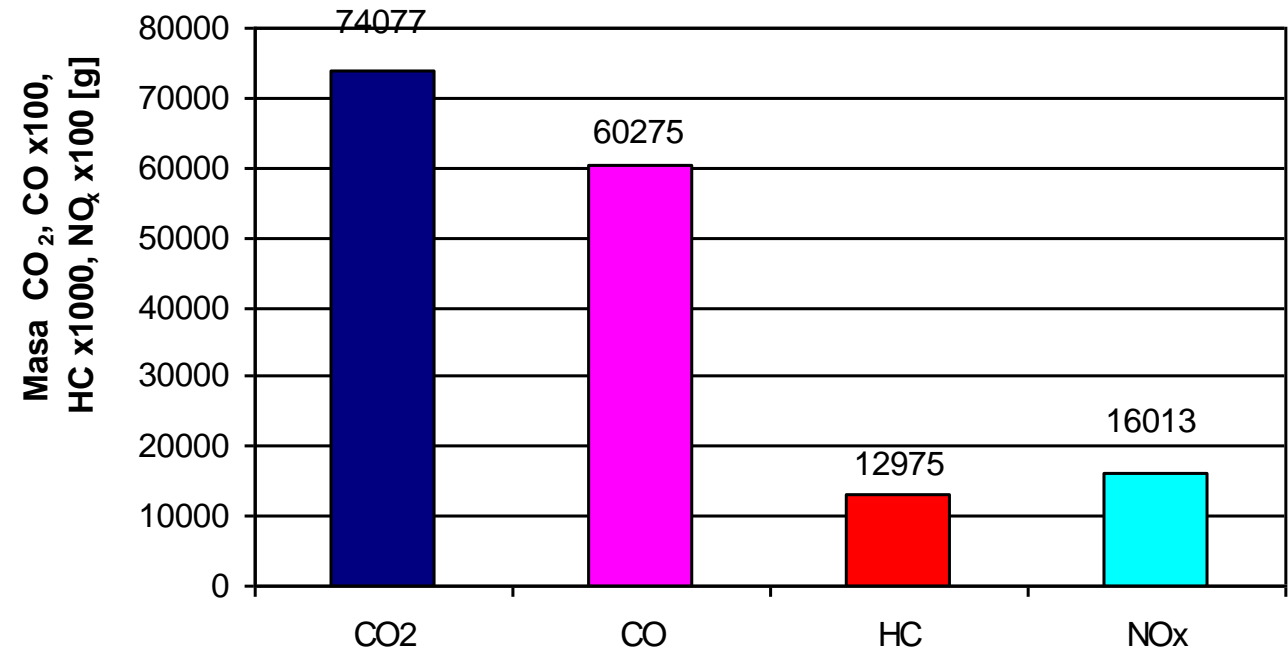

Rys. 13. Wartości masy związów szkodliwych spalin wygenerowana przez zespót napędowy śmigłowca podczas testu

Uzyskane przebiegi wartości chwilowej natężenia emisji poszczególnych związków szkodliwych poddano również zestawieniu z chwilowymi wartościami obciążenia silników zarejestrowanych przez pokładowy rejestrator parametrów lotu. Z takiego zestawienia uzyskano wartości emisji jednostkowej związków szkodliwych spalin dla poszczególnych punktów obciążenia silnika (rys. 14). Z uzyskanych danych wynika, że największym obciążeniem ekologicznym podczas realizowanej próby jest faza uruchomienia i rozgrzewania silnika na małych wartościach obciążenia.

Wraz ze wzrostem obciążenia obserwuje się zmniejszenie wartości emisji jednostkowej związków szkodliwych. Szczególnie jest to widoczne w przypadku emisji tlenku węgla i węglowodorów. Natomiast wartości emisji jednostkowej dwutlenku węgla i tlenków azotu zmieniają się w niewielkim zakresie dla odciążenia $65 \div 84 \%$. 
The assessment of toxic emission from the engines of the W-3 helicopter... Ocena emisji związów szkodliwych spalin z silników śmigłowca PZL W-3 Sokót...

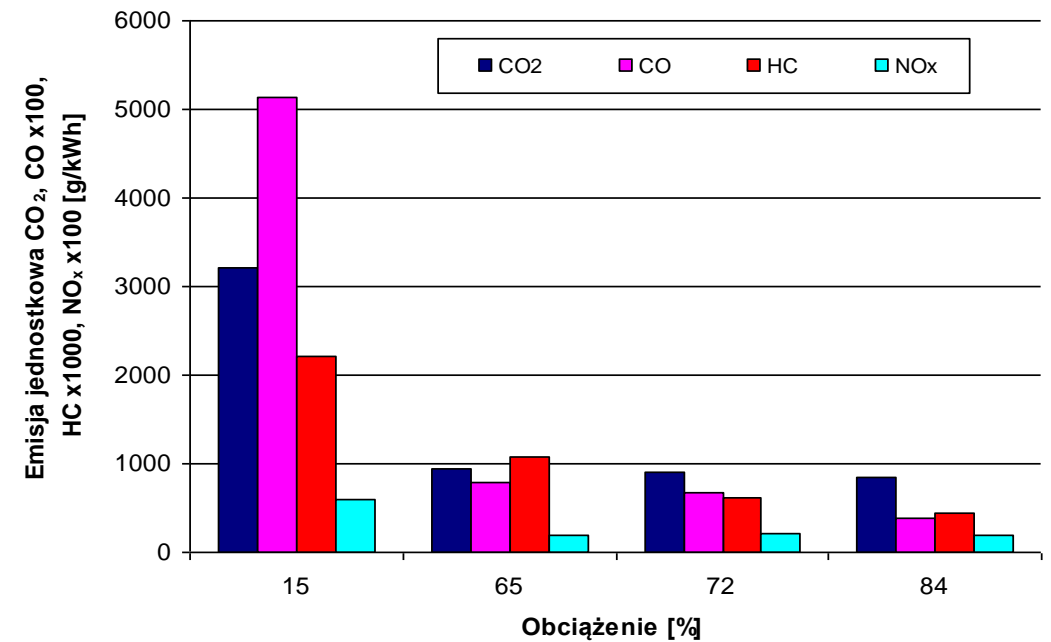

Rys. 14. Wartości emisji jednostkowej związów szkodliwych spalin generowana przez zespół napędowy śmigłowca przy poszczególnych wartościach obciążenia

Wartości emisji jednostkowej związków szkodliwych zawartych w spalinach wyznaczone dla poszczególnych obciążeń silnika, można pomnożyć przez procentowy udział czasu stanu obciążenia silnika podczas realizowanej próby przedlotowej. Uzyskuje się w ten sposób wartości emisji jednostkowej związków szkodliwych będących indywidualną charakterystyka danego silnika w danej próbie przedlotowej (rys. 15). Emisja jednostkowa $\mathrm{CO}_{2}$ wyniosła około 1450 $\mathrm{g} / \mathrm{kWh}$, CO około 16,70 g/kWh, HC około 0,580 g/kWh, $\mathrm{NO}_{\mathrm{x}}$ około 2,90 g/kWh.

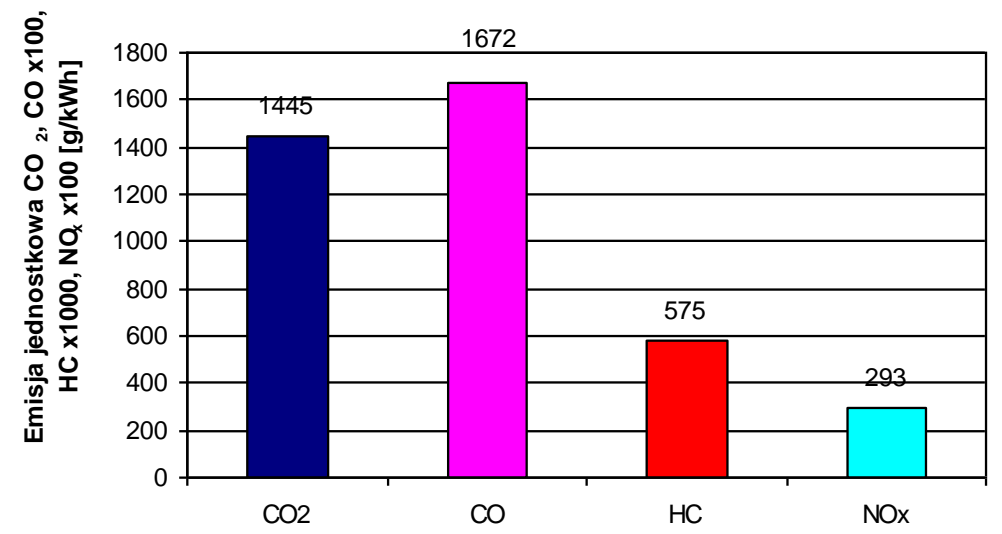

Rys. 15. Wartości emisji jednostkowej zwiazków szkodliwych spalin wygenerowana przez zespót napędowy śmigłowca podczas testu 


\section{Podsumowanie}

Przeprowadzone badania emisyjności śmigłowca PZL W-3 Sokół podczas próby przedlotowej pozwoliły uzyskać informacje o stężeniu związków szkodliwych zawartych $\mathrm{w}$ spalinach silnika turbinowego śmigłowcowego. Dalsza analiza uzyskanych wyników w zestawieniu z parametrami eksploatacyjnymi silników pozwoliła na uzyskanie wartości masy wyemitowanych związków szkodliwych spalin podczas próby oraz pozwoliła na oszacowanie wartości emisji jednostkowej tych związków.

Masa wyemitowanych związków szkodliwych wyznaczona w próbie przedlotowej może być wskaźnikiem emisyjności uzyskiwanych w takich warunkach, a jednocześnie może posłużyć do oceny stanu technicznego obiektu i możliwości jego dalszego wykorzystania. Wartości emisji jednostkowej związków szkodliwych, mogą posłużyć do porównania różnych jednostek napędowych śmigłowców bez konieczności wykonywania czasochłonnych testów badawczych. Mogą być również wykorzystane do oceny rzeczywistej emisyjności związków szkodliwych spalin z zespołów napędowych śmigłowca podczas lotu.

\section{Literatura}

[1] Antas S.: Wyznaczanie parametrów i osiągów silników śmigłowych i śmigłowcowych w przypadku modyfikacji przez zmianę temperatury spalin. Silniki Spalinowe 4/2006.

[2] Dzierżanowski P., Kordziński W., Otyś J., Szczeciński S., Wiatrek R.: Turbinowe silniki śmigłowe i śmigłowcowe. Wydawnictwa Komunikacji i Łączności, Warszawa 1985.

[3] J. Merkisz, J. Markowski, J. Pielecha, "Selected Issues in Exhaust Emissions from Aviation Engines" Air, Water and Soil Pollution Science and Technology. NOVA publishers, New York 2014.

[4] Witkowski R.: Wprowadzenie do wiedzy o śmigłowcach. Wydawnictwa Naukowe Instytutu Lotnictwa, Warszawa 2003.

[5] Budowa i zasada działania silnika PZL-10W. Materiały dydaktyczne, Wyższa Szkoła Oficerska Sił Powietrznych, Dęblin.

[6] Instrukcja obsługi analizatora Semtech-DS.

[7] Załącznik 16 do Konwencji o międzynarodowym lotnictwie cywilnym ICAO. Tom II Emisje z silników statków powietrznych. Załącznik do Obwieszczenia nr 15 Prezesa Urzędu Lotnictwa Cywilnego z dnia 26 kwietnia 2010 r. 
The assessment of toxic emission from the engines of the W-3 helicopter... Ocena emisji związów szkodliwych spalin z silników śmigłowca PZL W-3 Sokót...

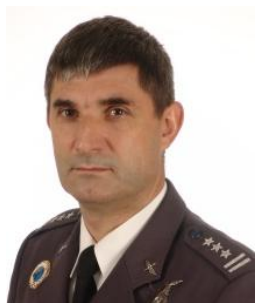

ptk dr inż. pil. Krzysztof CUR

Dowódca 8. Bazy Lotnictwa Transportowego

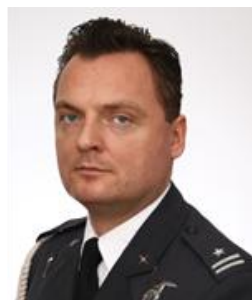

mjr dr inj. pil. Robert Koztowski

Specjalista, Inspektorat Ministerstwa Obrony Narodowej ds. Bezpieczeństwa Lotów w Poznaniu.

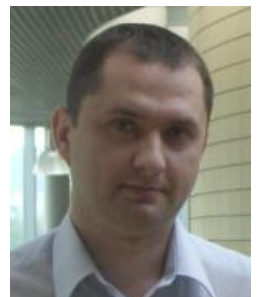

dr hab. inz. Jarostaw Markowski

Adiunkt na Wydziale Maszyn Roboczych i Transportu Politechniki Poznańskiej.

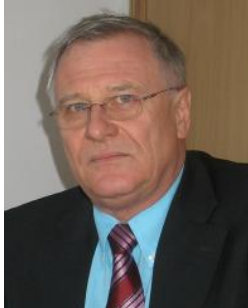

prof. dr hab. inz. Jerzy Merkisz

Profesor na Wydziale Maszyn Roboczych i Transportu Politechniki Poznańskiej.

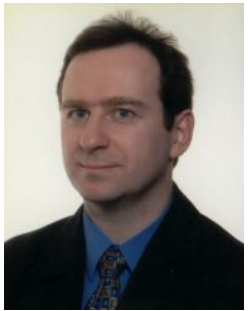

dr hab. inz. Jacek Pielecha, prof. PP

Profesor na Wydziale Maszyn Roboczych i Transportu Politechniki Poznańskiej. 